\title{
ECOLOGY OF SPANISH SEMIARID STREAMS
}

\author{
M.R. Vidal-Abarca, M.L. Suárez and L. Ramírez-Díaz \\ Animal Biology and Ecology Department. University of Murcia. Campus de Espinardo. 30100 Murcia, Spain
}

Keywords: Semiarid streams, Perturbations and disturbances, Floods, Aquatic invertebrates, Ecological unpredictability.

\begin{abstract}
This chapter analyses the limnological peculiarities of Spanish semiarid streams. Their hydrological regime vary on spatial and temporal scales depending on precipitation patterns. Their hydrological cycles are severely disturbed, in a fairly unpredictable way, by flash floods.

Variations in physico-chemical parameters, especially on a temporal scale are highly variable due to floods, which make it difficult to stablish hydrochemical models in the short term. In response to this regime of disturbances, communities of aquatic organisms show distinct ecological characteristics. The adaptative strategies of organisms vary considerably and seem to respond to the unpredictability of the disturbances.

Additionaly, the perspectives and future research lines of the group on the Ecology of Inland Waters of the University of Murcia are commented.
\end{abstract}

\section{INTRODUCTION}

The term "semiarid" is applied in this chapter to regions where, for different reasons, the balance of water is negative, creating an environmental stress which, unlike those occurring in arid lands or deserts, is neither permanent nor predictable. This condition is associated to particular climatic characteristics, primarily the pattern of rains, which determines a very characteristic hydrological regime on a pluriannual scale. The streams in these regions are subject to natural disturbances (droughts and floods), as a consequence of their irregular regime.

In Spain, two regions exist with semiarid climatic characteristics, situated in the South-east and in the central region of the Ebro depression (fig. 1). The latter, however, due to different topographical, geological and hydrological factors constitutes an endorrheic region disconnected from the fluvial network (MONTES \& MARTINO, 1987). In the Iberian South-east, the more abrupt and erosive topography makes drainage exorrheic giving rise to semiarid streams that are the subject of this chapter.

Very few bibliographic references exist concerning the structure and functioning of Spanish semiarid streams. Only scattered information is available about the changes of the physical or chemical parameters after a flood (AVILA,
1984; ESCARRE et al., 1984; VIDAL-ABARCA, 1985; SUAREZ, 1986; PUIG et al., 1987), or the washing and sweeping away of algae (SABATER, 1981) and macroinvertebrates populations (PRAT et al., 1986, PUIG et al., 1990; SOLER, 1991).

The group on Ecology of Inland Waters of Murcia University has recently published some of the results of its studies on semiarid streams, of the Iberian South-east (ORTEGA, 1988; ORTEGA et al., 1988; 1991a,b; VIDALABARCA, 1990, etc).

\section{ENVIRONMENTAL CHARACTERISTICS OF SPANISH SEMIARID REGIONS AND THEIR LIMNOLOGICAL IMPLICATIONS}

Any discussion on semiarid streams has to deal with the temporal and even the ephemeral character of the waterflow. However, these streams are not found exclusively in these semiarid regions. In Spain, as in other parts of the world, there is a great variety of terms that refer to the interruption of the water-flow in a channel ("torrent", "torrentera" and "riera" in the Catalan countries; "torrents" in the Balearic Islands; "yasa" in Aragon; "clamor" in the Aragon region of Monegros, and other of a more generalized use, 

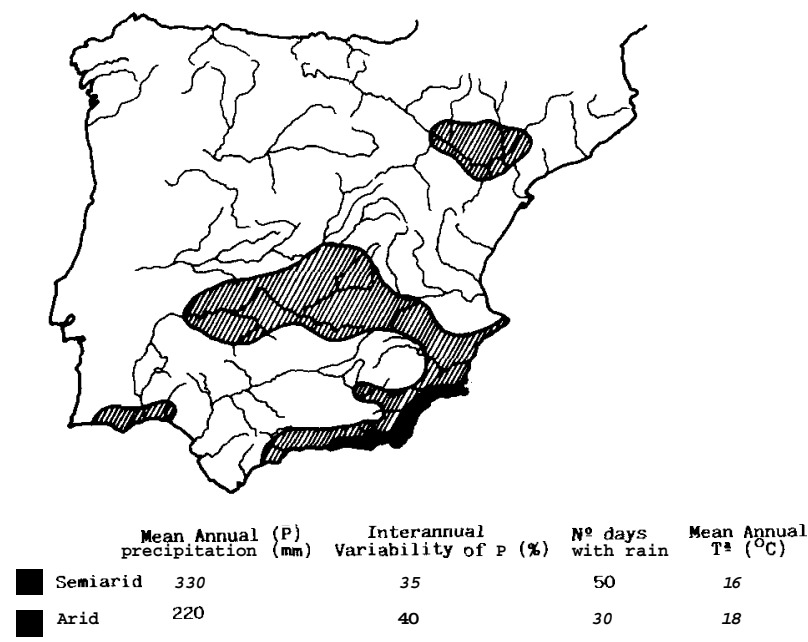

Fience 1 . Arid and semiarid Spanish regrons and some climatic parameters (modified from GARCIA DE PEDRAZA, 1989).

such as "cárcava", "barranco", "rambla", etc; ARENILLAS \& SAENZ, 1987). +Besides, in the semiarid Iberian Southeast, streams with permanent water, are also found.

The singularity of these streams is due to their hydrological regimes, which are very variable on both spatial and temporal scales. On a spatial scale it is possible to distinguish channels with permanent water (with a continuous flow during complete hydrological cycles), channels with temporary water (that remain dry or have a discontinuous flow in the summer season) and ephenieral channels (that only carry rapidly flowing water after strong storms). Moreover the same channel may liave sections of different typology. Figure 2 shows the drainage network of the Segura river basin (Iberian Southeast) according to the time during which water remains in its channels. As can be seen all possible combiriations and situations are observed.

Temporal variability in water-flow represents one of the most significant stressing elements both during an annual hydrological cycle and at a pluriannual level. Figure 3A, shows monthly flows and the daily maxima of the Rambla del Moro, one of the semiarid tributaires of the Segura river in the Iberian South-east (fig. 2). As can be observed the irregularity of the flows during the study period, was extreme (from $0 \mathrm{~m}^{3} /$ month to $227.146 \mathrm{~m}^{3} /$ month). The maximum values correspond to floods, a natural hydrological phenomenon that disturbs the whole system, basically because its occurrence is quite unpredictable. Fig. 3B, shows the number of floods that occursed in the Segura river between the years
826 and 1990 . The scarcity of data during certain periods makes it difficult to stablish any regularity, even on a pluriannual scale, where sequences of these events are repeated.

These hydrological models are the consequence of the peculiar climate of semiarid regions. Of all the climatic parameters usually used to define the climate of an area, the most important is the pattern of precipitations. Figure 4 shows temperature and precipitation diagrams (A) and the value of the annual precipitation in relation to its median (B), during a period of 41 years, in various termopluviometric gauges situated in the Segura river basin. All of these explains the peculiarities of the precipitation patterns in the Spanish South-east: Its seasonal variability on the one hand, and its scarce predictability, on the other, when pluriannual cycles are analysed.

As a consequence of the above, it is easy to deduce that the biological communities which inhabit these streams, find themselves subjected to considerable natural disturbances that determine their structure and the functioning of the whole system.

\section{ASPECTS ABOUT STRUCTURE AND FUNCTIONING OF SPANISH SEMIARID STREAMS}

\section{Hydrochemical patterns}

Floods are one of the most important natural hydrological disturbance phenomena of Spanish semiarid streams. Changes in the physico-chemical parameters induced by a flash flood (October 7th, 1986) in the Rambla del Moro, a spatially intermittent stream located in the East of the Segura river basin (fig. 2), were studied analyzing the water during ten days after the flood. Suspended solids, alkalinity and nutrients (nitrate-nitrogen and phosphatephosphorus) increased markedly after the flood while conductivity declined quickly in relation to the discharge peaks (fig. 5).

However, this situation is sporadic and only occurs when flooding takes place. Problems related to the general hydrological system are encountered when trying to stablish the hydrochemical models of these streams. An intesive study on the variations in the hydrochemistry of Mula river (one of the main tributaries of the Segura river: fig. 2) made it possible to establish that, on a spatial level, the physicochemical characteristics of the river could be explained by two components: the mineralization of the water and the 


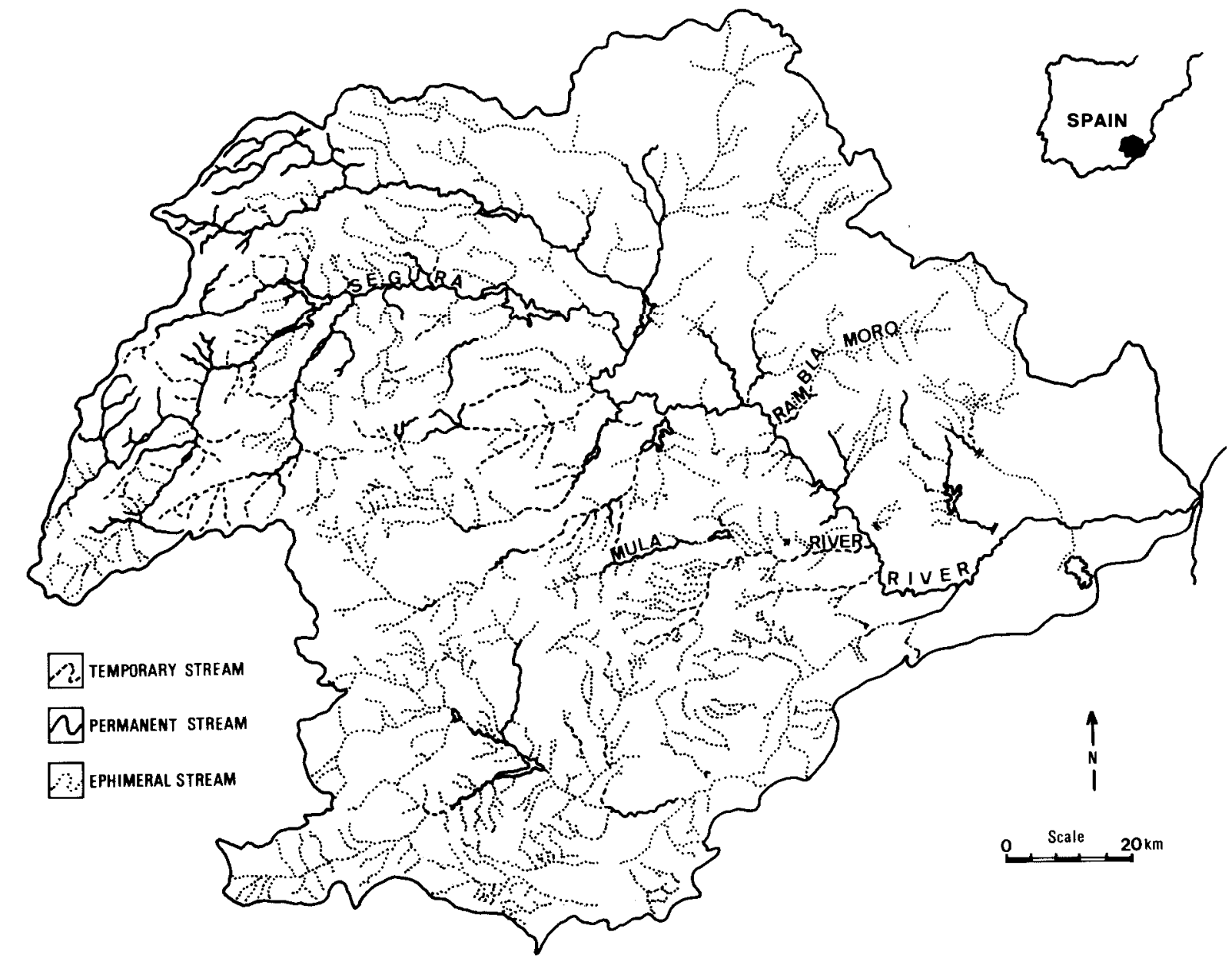

Figure 2. Drainage network of the Segura river basin (SE of Spalm).

organic contamination processes (fig. 6A). The former related to the geological materials of the drainage basin and the latter to organic waste from riverside towns. Those two processes are spatially interrupted due to the fact that the Mula river flows only in two sections that are independent from each other. On a temporal scale and after having studied two complete hydrological cycles it turned out that the physico-chemical parameters showed a high degree of variability and no regular patterns could be found (fig. 6B) (SUAREZ, 1986).

In short, on a spatial scale, the discontinuity of the waterflow determines that the variations of the physico-chemical parameters depend more on external environmental factors than in streams with a continuous flow, where processes of chemical stabilization take place down-stream. On a temporal scale, hydrochemical variations are quite unpredictable and appear to be subjected to the alternating floods and droughts.

\section{Communities of aquatic organisms}

Faced with the situation described in the previous paragraph, communities of aquatic organisms show ecological characteristics that are difficult to define. To begin with their qualitative composition is different from that of most other temperate streams. The typical communities of rivers are composed of different species of mayflies, stoneflies, caddis flies and reophyle flies. In Spanish semiarid streams the flies, water bugs, water beetles, dragonflies and damselflies are the species that broadly dominate the aquatic invertebrate communities (VIDAL-ABARCA, 1990). Table 1, exemplifies the qualitative composition and abundance of the aquatic invertebrate community in the Rambla del Moro at different times of the year.

This peculiar qualitative composition could possibly be interpretated as an adaptative strategy towards the natural 


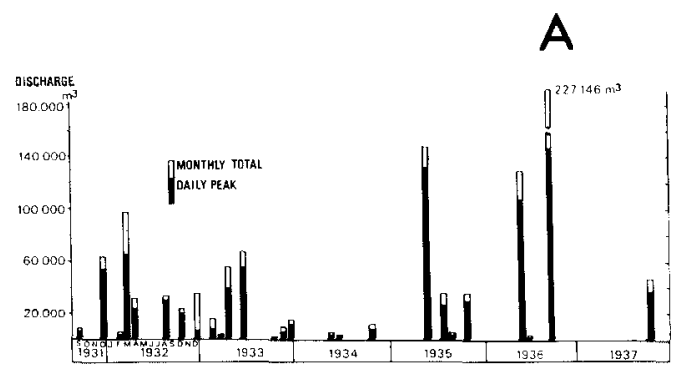

B

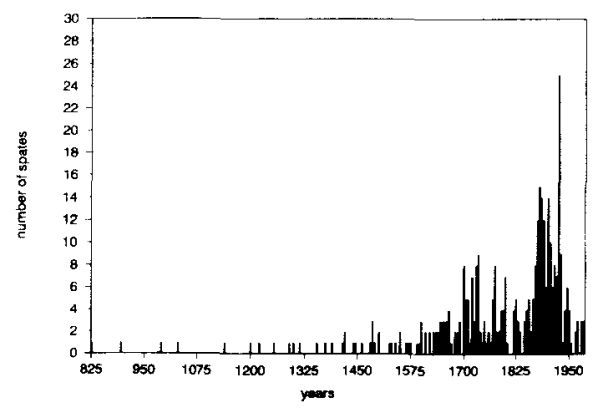

Figure 3. A: Monthly runoft in the Rambla del Moro, for the 1931 1937 period (from LOPEZ BERMUDEZ et al., 1986). B: Number of spates in Segura Kiver from 826 to 1990.

disturbances to which these streams are subject. Although there is a lack of studies on the biology, ecological requirements and life cycles of the species of aquatic invertebrates of Spanish semiarid streams, there is some information which is curious to analyze. Thus, Heliocorisa vermiculata a water bug inhabiting the Rambla del Moro, produces at least, four generations a year and the adults are typically winged in autum, that is precisely the season of the year during which the probability of flood occurrance is greatest (VELASCO et al., 1990). Futhermore, the importance of these winged adult insects during the process of post-flood recolonization in the Rambla del Moro has been demostrated (ORTEGA et al., 1991a). Finally it has been detected that the larvae of the insects collected from these streams are smaller in size than those normally described in the bibliography, which could have an adaptative significance as yet undiscovered (ORTEGA et al.. 1991b). In short, it seems that the winged adults of these aquatic insects that inhabit these streams are the adaptative forms to these disturbances.

The theories concerning disturbance and stability in ecosystems (SOUSA, 1984) have recently been a focus of research in stream ecology (WISSMAR, 1988). Stability describes ecosystem response to disturbance and implies resistence, the capacity to avoid change, and resilience, the ability to recorver rapidly after disturbance. Both may be equally important for obtaining the system's stability once the disturbance has taken place. The analysis of available information seems to indicate that following floods, in Spanish semiarid streams the communities of aquatic organisms show very low resistance and very high resilience. In this way a flash flood occurring in the Rambla del Moro in october 1982 eliminated $99 \%$ of the taxa of aquatic invertebrates present at the time, whilst the one occurring in 1986 reduced the number of taxa to half. However in this last case the community had practically reestablished itself 27 days after the flood had taken place (ORTEGA er al., 1991b). The magnitude of the disturbance must undoubtedly be more directly related to the resistance of the community, whereas its frequence is related to the resilience. Since the degree of predictability of the floods in the Iberian South-east can be considered average (fig. 3B) when compared to mesic streams where floods are more frequent and periods between disturbances shorter. According to this. a certain degree of diversification in the adaptative strategies of the species and an average capacity to recolonize the disturbed streams can be expected. Table 2 shows a qualitative comparative analysis of different abiotic and biotic variables in relation to flash-floods, in three streams where floods occur (Sycamore creek, Arizona desert; Le Rdat, Morocco and Rambla del Moro, Spain). As can be seen there is a tendency of aquatic invertebrates to diversify their adaptative mechanisms and recolonization pathways as a response to the unpredictability of floods.

The combination of complex mechanisms used by aquatic organisms to reestablish the community after a flash flood, together with strategies compensating these disturbances allows to stablish simple models to understand the dynamics of these communities. A simple example was obtained by analysing the different means of recolonization used by the aquatic invertebrates in the Rambla del Moro after the flash flood of 1986. Four principal means of stream invertebrate recolonization are identified: drift, upstream movement, movement from the hyporheic zone and oviposition from aerial adults (WILLIAMS, 1981). In our study, upstream movement and movement from the hyporheic zone were not analysed because flash floods produce a very large wash downstream and the study site was located at the mouth of the rambla and the channel bed consisted of gravel and compacted clay respectively. On the other hand, the 
A

B
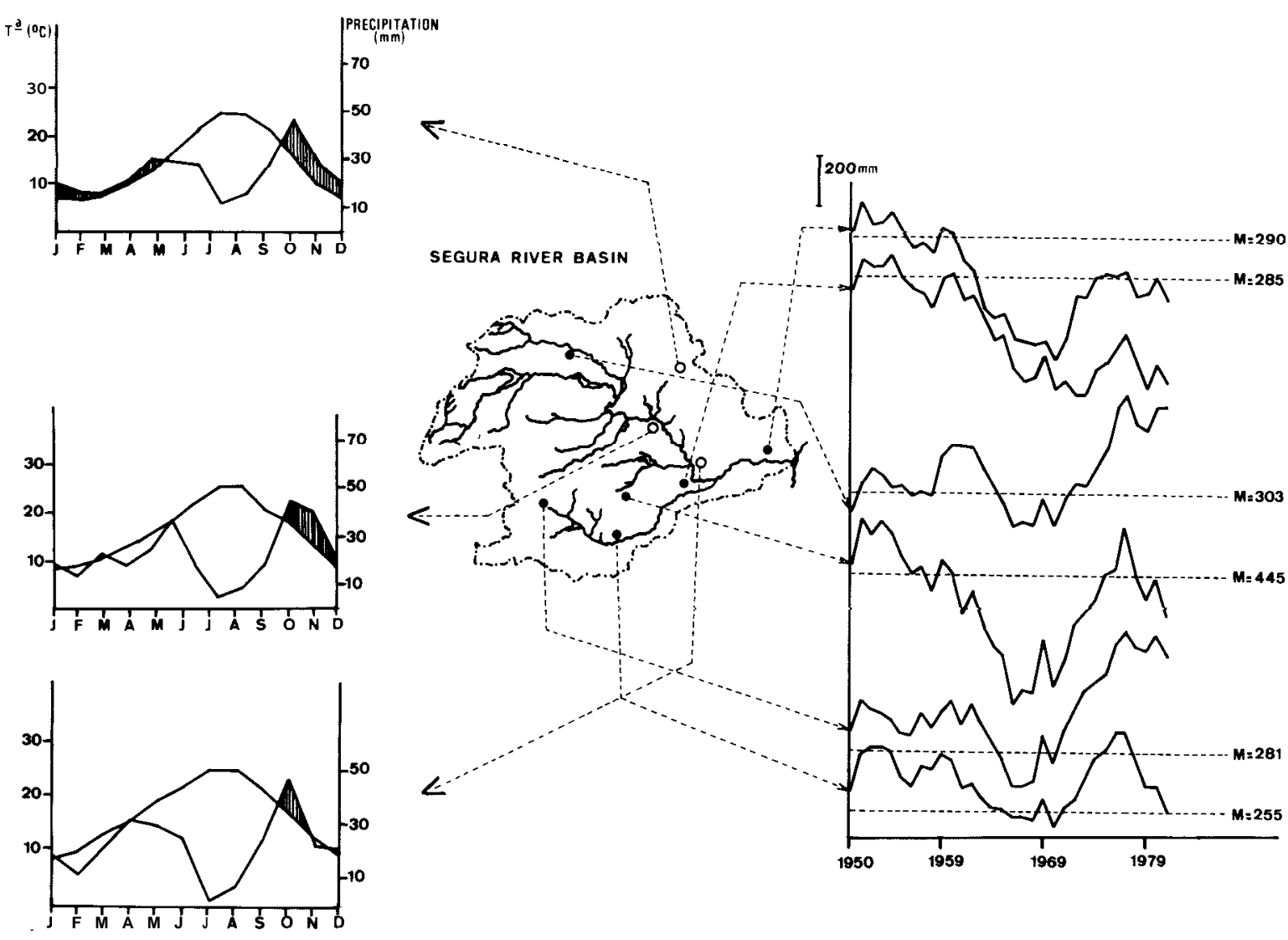

Figure 4. A: Temperature and precipitation diagrama of different zones in the Segura river basin. B: Annual precipitation respect to median (M) of different zones in the Segura river basin.

Table 1. Specific richness and abundance of aquatic invertebrate community of the Rambla del Moro, for autumn, winter and summer.

\begin{tabular}{|c|c|c|c|c|c|c|}
\hline \multirow{3}{*}{$\begin{array}{l}\text { INVERTEBRATE } \\
\text { TAXA } \\
\text { MOLLUSCA }\end{array}$} & \multicolumn{2}{|c|}{ AUTUMN } & \multicolumn{2}{|c|}{ WINTER } & \multicolumn{2}{|c|}{ SUMMER } \\
\hline & \multicolumn{2}{|c|}{ N" Abund.(\%) } & \multicolumn{2}{|c|}{ № Abund. $(\%)$} & \multicolumn{2}{|c|}{ № Abund. $(\%)$} \\
\hline & 1 & 1.85 & 1 & 0.10 & 1 & 5.00 \\
\hline ACARINA & 1 & 0.05 & - & - & 1 & 0.06 \\
\hline CRUSTACEA & 1 & 0.12 & 1 & 0.27 & 1 & 8.38 \\
\hline EPHEMEROPTERA & 2 & 2.20 & 2 & 4.90 & 2 & 24.91 \\
\hline ODONATA & 7 & 1.15 & 1 & 0.18 & 5 & 2.01 \\
\hline HEMIPTERA & 11 & 59.14 & - & - & 6 & 1.49 \\
\hline COLEOPTERA & 10 & 30.77 & 8 & 5.45 & 11 & 49.02 \\
\hline DIPTERA & 9 & 4.72 & 12 & 89.10 & 10 & 9.13 \\
\hline TOTAL & 42 & & 25 & & 37 & \\
\hline
\end{tabular}


movements and evolution of the aquatic invertebrates that remained in marginal ponds, formed by the flood were analysed.

Figure 7 schematices the movements of aquatic invertebrates during and after flash flood (ORTEGA et al., 1991a). During flash flood (fig. 7A) two different displacement uncontrolled by the species were detected ("uncontrolled phase"). Many invertebrate populations are washed out
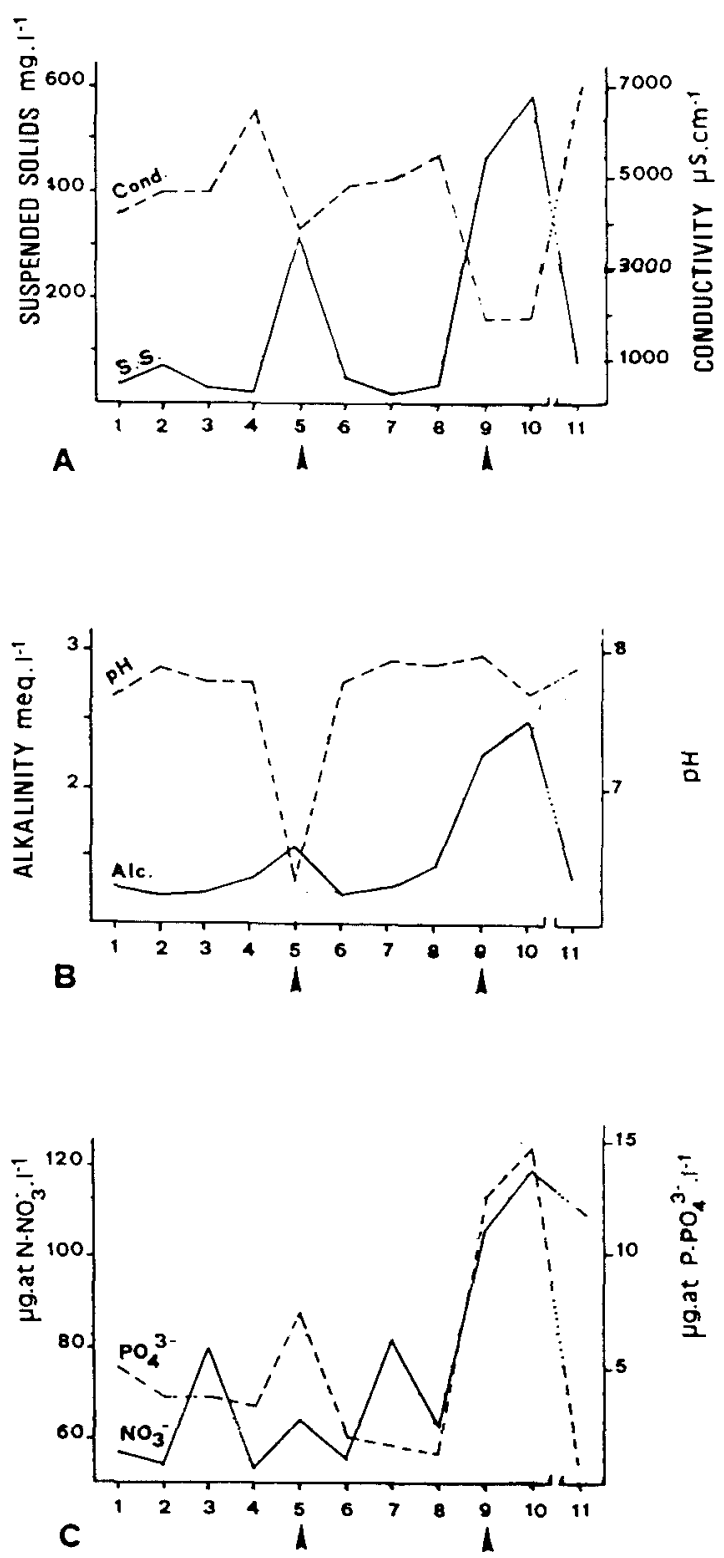

Figure 5. Suspended solids and conductivity (A), alkalinity and $\mathrm{pH}$ (B), nitrate-nitrogen and phosphate-phosphorus (C), after the flood in the Rambla del Moro. Arrows denote the timing of mayor flood peaks. downstream by "exceptional" or "catastrophic" drift (sensu WATERS, 1964). Other species are displaced laterally and deposited on the flood-plain. Both movements are an inmediate consequence of flash flood, which disturbs and disorganizes the invertebrate community of the Rambla del Moro.

After flooding, invertebrate movements try to reorganize the community and this phase has been called "controlled and predicted phase" (fig. 7B). By ordinary drift, 27 taxa which belong to the invertebrate community of the Rambla del Moro moved downstream. However, the most important invertebrate movements originated in marginal ponds. 17 taxa returned to the channel in the days following flood. These taxa used several displacement methods: the snail Mercuria confusa and the fly Stratiomys sp. crawled over humid mud, while the water bug Nepu cinerea and water beetle Hydrous pisceus walked. Many adult water beetles can fly, so many flew alternatively from pond to channel and viceverse according to flow fluctuations. Adult dragonflies used the channel and the marginal ponds for oviposition. However, hatching larvae could not survive in the marginal ponds because the ponds dried out after 15 days.

\section{PERSP'ECTIVES AND FUTURE RESEARCH}

It is evident that to achieve an understanding of the complexity of the processes that occur in Spanisin semiarid streams, it is necessary to analyse them from differ. 't perspectives, on a multidimensional scale, incorporating the extensive range of spatial variations a $d$ the temporal scale at different magnitudes.

In this way an initial approximation wuuld involve defining the most important environmental factors that would explain the spatial heterogeneity of these streams. Some investigations have revealed how different topographical, morphometrical, geological and hydrological parameters can explain the continuity and discontinuity of the water-flow in Spanish semiarid streams.

The mosaic structure that the topographic relief of the Iberian South-east shows alternating large depressions and elevations together with a type of geological substrate, generally soft and easily erosionable, which facilitates the formation of complex aquatic systems called "the wadi-complex" by GONZALEZ BERNALDEZ (1988). These systems include a permanent or temporary stream ("rambla") to which small wetlands are associated in the form of patches. This structure seems to be the response of the drainage 
Table 2. Qualitative comparative table of different abiotic and biotic variables about flash-floods in Sycamore creek: Arizona (data from GRAY, 1980; 1981; GRAY \& FISHER, 1981); Le Rdat: Moroccco (data from BADRI et al., 1987) and Rambla del Moro: Spain.

\begin{tabular}{|c|c|c|c|}
\hline & $\begin{array}{l}\text { Sycamore Creek } \\
\text { (Arizona) }\end{array}$ & $\begin{array}{l}\text { Le Rdat } \\
\text { (Morocco) }\end{array}$ & $\begin{array}{l}\text { Rambla del Moro } \\
\text { (Spain) }\end{array}$ \\
\hline Type of stream & desert stream & $\begin{array}{l}\text { arid stream from } \\
\text { Mediterranean area }\end{array}$ & $\begin{array}{l}\text { semiarid stream from } \\
\text { Mediterranean area }\end{array}$ \\
\hline Floods intensity & medium & medium-high & variable \\
\hline Floods frecuency & $\begin{array}{l}\text { high (winter, } \\
\text { spring, summer) }\end{array}$ & medium (spring) & $\begin{array}{l}\text { medium-low } \\
\text { (autum) }\end{array}$ \\
\hline Floods predictability & high & high & medium \\
\hline Invertebrate taxa & $\begin{array}{l}\text { water-beetles, } \\
\text { flies, caddis- } \\
\text { flies, water } \\
\text { bugs }\end{array}$ & $\begin{array}{l}\text { flies, water- } \\
\text { beetles,caddis- } \\
\text { flies, mayflies }\end{array}$ & $\begin{array}{l}\text { flies, water-beetles, } \\
\text { water-bugs, dragonflies } \\
\text { damselflies }\end{array}$ \\
\hline Invertebrate richness & 48 & 38 & 61 \\
\hline Resistance & low & low & medium \\
\hline Resilience & high & medium-high & medium \\
\hline $\begin{array}{l}\text { Recolonization } \\
\text { pathways }\end{array}$ & $\begin{array}{l}\text { oviposition from } \\
\text { aerial adults }\end{array}$ & $\begin{array}{l}\text { drift, movements } \\
\text { from floodplain }\end{array}$ & $\begin{array}{l}\text { drift, movements from } \\
\text { floodplain, oviposition } \\
\text { from aerial adults }\end{array}$ \\
\hline Adaptative mechanisms & $\begin{array}{l}\text { life cycles short, } \\
\text { invertebrates } \\
\text { producing several } \\
\text { generations anriually, } \\
\text { temporal sustitution } \\
\text { of species. }\end{array}$ & $\longrightarrow$ & $\begin{array}{l}\text { variable life cycles, } \\
\text { invertebrate size small, } \\
\text { no temporal sustitution } \\
\text { of species }\end{array}$ \\
\hline
\end{tabular}




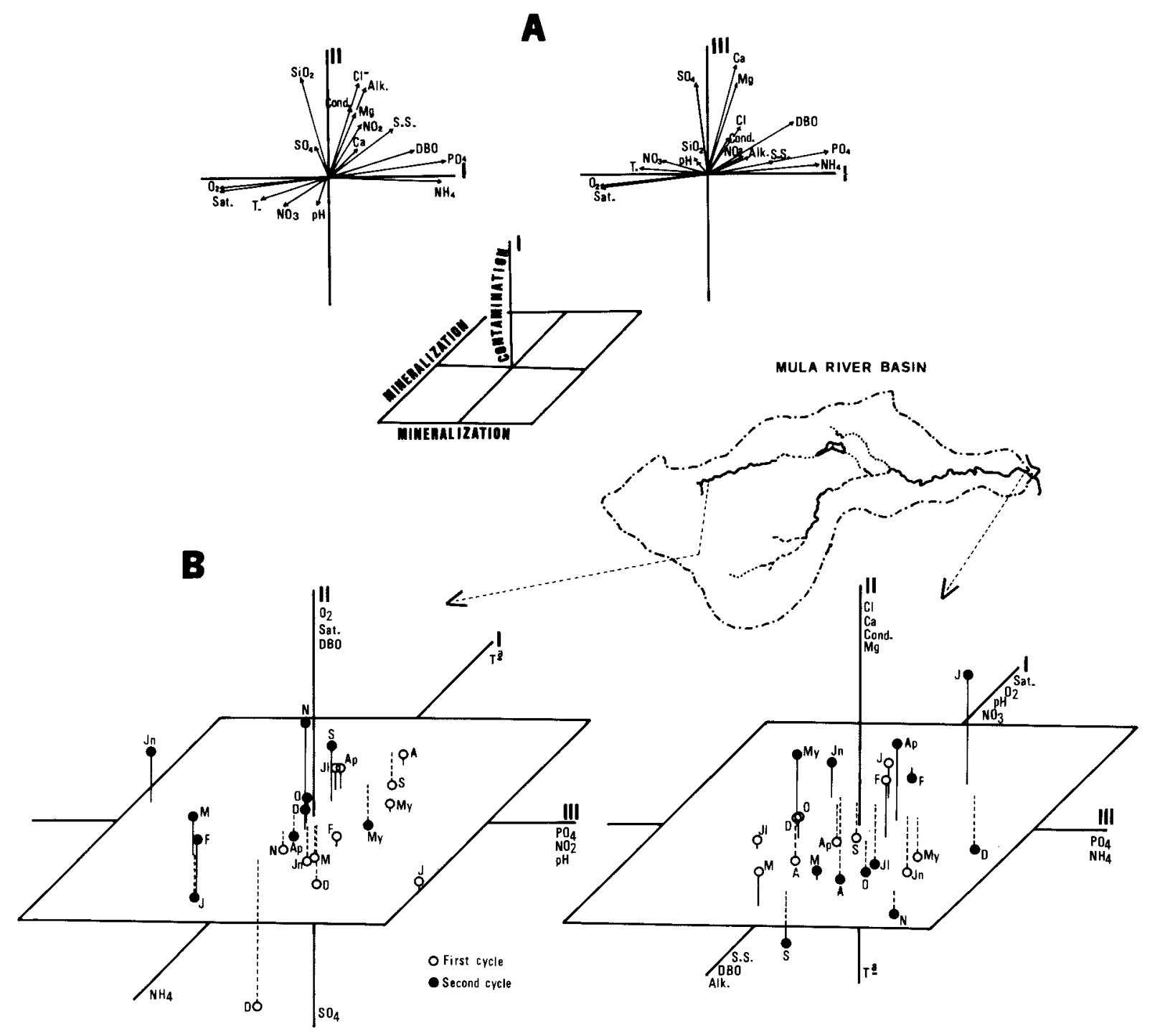

Figure 6. A: Relative position of physico-chemical parameters measured in 51 sampling stations located in the Mula river basin, during summer, in the planes defined by axes 1-11 and I-III of the Factor Analysis, and environmental interpretation of these axes. B: Projection of samples (months) in the plane defined by the first three axes of Factor Analysis, of two sampling stations located in the Mula river. Alk. = Alkalinity; Cond.$=$ Conductivity; Sat. $=\%$ Saturation of dissolved oxygen; S.S. $=$ Suspended solids .

system to the floods. The role of the floods in the genesis or disappearance of these wetlands is another objetive of current investigation.

These "wadi complex" must have an essential role in the dynamics of the nutrients of the associated streams. The studies that we are currently initiating will possibly explain the spatial and temporal hydrochemical models of Spanish semiarid streams.
On the other hand, the studies on the adaptative behaviour of aquatic invertebrate species in these streams continue to be the main research objetive. Undoubtedly, the accumulation of information (intensity, frequency, magnitude, etc) of the disturbances of Spanish semiarid streams and the analysis of the life cycles and ecological requirements of the invertebrates species, will enable to stablish reliable models of their dynamics. 


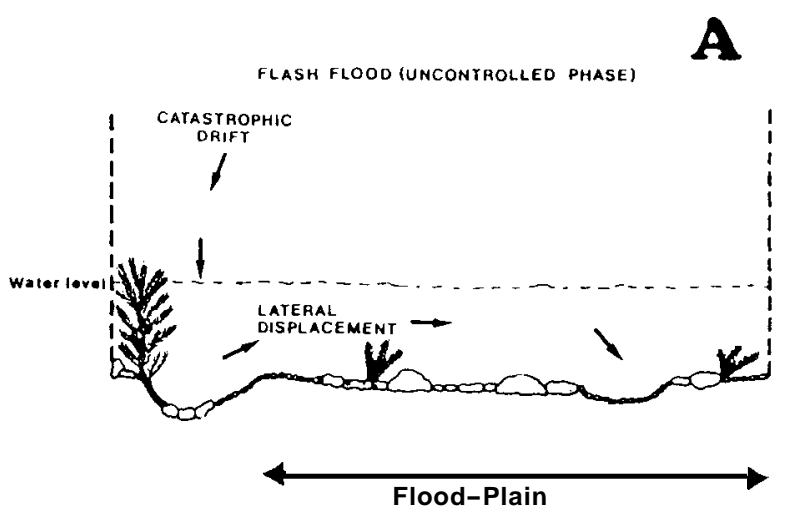

$\mathbf{B}$

MOVEMENTS TO REORCANIZE THE BENTHIC COMMUNITY (CONTROLLEO ANO PREDICTEO PHASE)

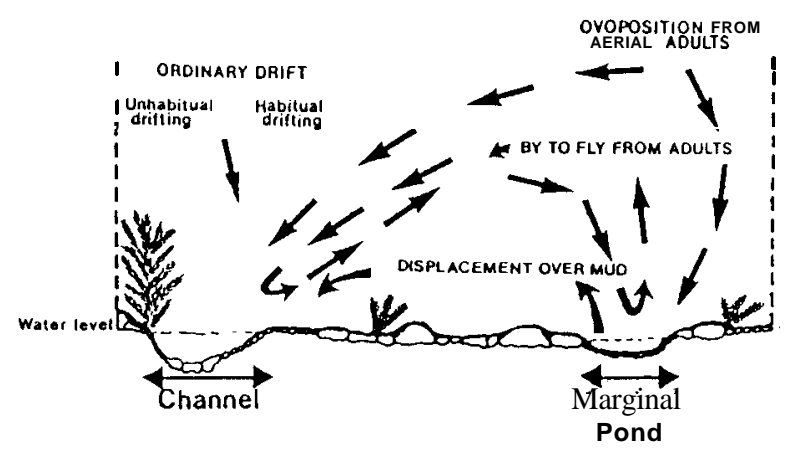

Figure 7. Summary of invertebrate taxa movements ocurring during (A) and after (B) flood, in the Rambla del Moro (modified from ORTEGA et al., 1991a).

Additionally, another objetive of the work has an applied character and pretends to design a complex methodology to made possible elaborate maps with associated risk of floods. This will be most usefull for the studies on territorial planning.

\section{ACKNOWLEDGEMENTS}

To Dr. F. Torrella for reviewing the english paper.

\section{REFERENCES}

ARENILLAS, M. \& C.SAENZ. 1987. Guia Física de España. 3.-Los ríos. Alianza Editorial. Madrid.
AVILA, A. 1984. Composición química de los arroyos del Montseny (Barcelona). Limnética 1(1): 128-135.

BADRI, A; J.GUIDICELLI \& G.PREVOT. 1987. Effects d'une crue sur la communaute d'invertébrés benthiques d'une riviere méditerranéenne, Le Rdat (Maroc). Acta Oecologica. Oecol. Gener., 8(4): 481-500.

ESCARRE, A.; C.GRACIA; F.RODA \& J.TERRADAS. 1984. Ecología del bosque esclerófilo mediterráneo. Investigación y Ciencia, 95: 69-78.

GARCIA DE PEDRAZA, L. 1989. Climas de transición al árido. Climas áridos, dominios áridos y semiáridos en España. In: Seminario sobre Zonas Aridas en España. 4563. Real Academia de Ciencias Exactas, Físicas y Naturales. Madrid.

GONZALEZ BERNALDEZ, F. 1988. Typology of wetlands and evaluation of the resources they represent. In: International Symposium on Hydrology of wetlands in Semiarid and arid regions. 7-36. Sevilla.

GRAY, L.J. 1980. Recolonization pathways and community development of desert stream macroinvertebrate. Disertation: Arizona State University.

GRAY, L.J. 1981. Species composition and life histories of aquatic insects in a Lowland Sonoran Desert stream. Amer. Midland Natur., 106: 229-242.

GRAY, L.J. \& S.G. FISHER. 1981. Postflood recolonization pathways of macroinvertebrates in a Lowland Sonoran Desert stream. Amer. Midland Natur. 106: 249-257.

LOPEZ BERMUDEZ, F.; F.CALVO \& A.MORALES. 1986. Geografía de la Región de Murcia. Ketres Ed. Barcelona.

MONTES, C. \& P.MARTINO. 1987. Las lagunas salinas españolas. In: Bases científicas para la protección de los humedales españoles. 95-145. Real Academia de Ciencias Exactas, Físicas y Naturales. Madrid.

ORTEGA, M. 1988. La rambla del Moro (Cuenca del Río Segura). Ambiente, físico, biológico y alteraciones producidas por una riada. Tesis de Licenciatura. Univ. Murcia.

ORTEGA, M.; M.R.VIDAL-ABARCA; M.L.SUAREZ; J.L.GONZALEZ-BESERAN \& L.RAMIREZ-DIAZ. 1988. Características fisico-químicas de las aguas superficiales de la Rambla del Moro despues de una riada (Cuenca del Río Segura, SE de España). Limnética, 4: 19-26.

ORTEGA, M.; M.L.SUAREZ; M.R.VIDAL-ABARCA; R.GOMEZ \& L.RAMIREZ-DIAZ. 1991 a. Aspects of postflood recolonization of macroinvertebrates in a "Rambla" of south-east Spain ("Rambla del Moro": Segura River Basin). Verh. Internar. Verein. Limnol., 24: 1994-2001. 
ORTEGA, M.; M.L.SUAREZ; M.R.VIDAL-ABARCA \& L.RAMIREZ-DIAZ. 1991b. Aspectos dinámicos de la composición y estructura de la comunidad de invertebrados acuáticos de la Rambla del Moro despues de una riada (Cuenca del Río Segura: SE de España). Limnética, 7:11-24.

PRAT, N; G.GONZALEZ; I.MUÑOZ \& X.MILLET. 1986. Community structure and colonization process in a mediterranean drainage basin. Proc. 3rd Europen Cong. Entomol.: 121-124.

PUIG, M.A.; J.ARMENGOL; G.GONZALEZ; J.PEÑUELAS; S.SABATER \& F.SABATER. 1987. Chemical and biological changes in the Ter River induced by series of reservoirs. In: CRAIG, J. (ed.) Regulated Str-eam: Advances in Ecology. 363-373. Plenum Press.

PUIG, M.A.; M.FERRERAS \& A.GARCIA-ROJAS. 1990. Morphological variability of Tyrrhenoleuctra minuta (Klapalek, 1903) in south Spain. In: CAMPBELL, I.C.(ed.). Mayflies and Stoneflies. Kluwer Acad. Publ.

SABATER, S. 1981. Distribución espacio-temporal de las poblaciones de algas del arroyo de L'Avencó (Barcelona). Actas $1^{\circ}$ Cong. Limnología: 159-166.

SOLER, G. 1991. Pautus de migración de las comunidades hentónicas del Río Matarraña (Cuenca del Ebro) a lo largo de un ciclo anual y en función de la velocidad de la corriente y la heterogeneidad del sustrato colonizahle. Tésis de Licenciatura. Univ. Murcia.
SOUSA, W.P. 1984. The role of disturbance in natural communities. Ann. Rev. Ecol. Syst., 15: 353-391.

SUAREZ, M.L. 1986. Estructura y dinámica de la composición físico-química de las aguas superficiales de una cuenca de características semiáridas del sureste español (Río Mula: Cuenca del Segura). Tesis Doctoral. Univ. Murcia.

VELASCO, J.; A.MILLAN \& N.NIESER. 1990. Observaciones sobre la colonización y el ciclo de vida de Heliocorisa vermiculata (Puton, 1874) (Heteroptera, Corixidae) en pequeños estanques del SE español. Limnética, 6: 101-108.

VIDAL-ABARCA, M.R. 1985. Las aguas superficiales de la Cuenca del Río Segura (SE de España). Caracterización físico-química en relación al medio físico y humano. Tesis Doctoral. Univ. Murcia.

VIDAL-ABARCA, M.R. 1990. Los ríos de las cuencas áridas y semiáridas: Una perspectiva ecológica y de síntesis. Scientia gerundensis, 16: 219-228.

WATERS, T.F. 1964. Recolonization of denuded stream bottom areas by drift. Trans. Am. Fish. Soc., 93: 311-325.

WILLIAMS, D.D. 1981. Migrations and distributions of stream benthos. In: LOCK, M.A. \& D.D. WILLIAMS (eds.). Perspectives in running ecology. 155-207. Plenum Press. New York.

WISSMAR, R.C. 1988. The role of disturbance in stream ecology. J. N. Am. Benthol. Soc.,7(4): 433-455. 